\title{
SOCIAL CAPITAL AND THE MAKING OF DIASPORA: EVIDENCE FROM THE PORTUGUESE COMMUNITY OF JOHANNESBURG, SOUTH AFRICA
}

\author{
Maisa C. ADINOLFI* \\ School of Tourism and Hospitality, University of Johannesburg, 57 Bunting Rd, \\ Cottesloe, Johannesburg, 2092, Africa de Sud, e-mail: mcorreia@uj.ac.za
}

\begin{abstract}
Citation: Adinolfi M.C. (2019). SOCIAL CAPITAL AND THE MAKING OF DIASPORA: EVIDENCE FROM THE PORTUGUESE COMMUNITY OF JOHANNESBURG, SOUTH AFRICA. GeoJournal of Tourism and Geosites, 25(2), 555-568. https://doi.org/10.30892/gtg.25222-380
\end{abstract}

\begin{abstract}
Studies on diaspora and their links to tourism have more recently gained attention in academic literature, and have become a major theme in tourism scholarship. There is a gap, however, in understanding the role that social capital and networks play in constructing diasporic communities and identities, which can ultimately lead to curiosity around people's heritage and spark the desire to travel for heritage tourism and VFR reasons. The Portuguese diaspora in South Africa have roots dating back to the 15th century when European explorers first landed in the Cape. Since then, significant immigration events have occurred where the community has evolved and integrated into South African society at varying levels. There are numerous examples of the Portuguese social and economic footprint in the country but despite its significant presence, it has been for the most part under researched. The $1^{\text {st }}$ São Jorge Scouts Group is an instructive case study into how Portuguese immigrants in the wake of the wars in their previous homes in Angola and Mozambique, came together to create an identifiably Portuguese social group in the context of the international Scouting movement. This paper focuses on the making of diasporic communities and the particular role of social capital and networks in the construction of Portuguese identity retained by the scouts group, and contributes to the larger discourse on immigrant integration, sense of belonging and their links to tourism. Key interviews revealed fundamental areas of relevance to the diasporic experience, including notions of identity, the role of religious institutions and a developed sense of community and belonging.
\end{abstract}

Key words: diaspora, social capital, social networks, identity, Portuguese diaspora

\section{INTRODUCTION}

The concept of diasporas has been widely debated in the literature, from endeavours to define them (Cohen, 1997; Brubaker, 2005; King, 2012; Quayson \& Daswani, 2013; Alexander, 2017), discussions on their integration into host societies

\footnotetext{
* Corresponding author
} 
(Greenman \& Xie, 2008; Piedra \& Engstrom, 2009; Schneider \& Crul, 2010), the idea of transnationalism (Portes et al., 2002; Haller \& Landolt, 2005; Huang et al., 2013; Quayson \& Daswani, 2013), elements of identity and diaspora (Georgiou, 2006; BenMoshe \& Segev, 2007; Hall, 2014) and their links to tourism (Hughes \& Allen, 2010; Iorio \& Corsale, 2012; Pelliccia, 2016; Io, 2017). The very notion of the existence of diasporic communities lends itself to the possibilities of diaspora-induced tourism, including VFR travel and heritage tourism (Stephenson, 2002; Sim \& Leith, 2009; Hughes \& Allen, 2010; Iorio \& Corsale, 2012; Rogerson \& Hoogendoorn, 2014; Pelliccia, 2016; Io, 2017; Rogerson, 2017). However, it is the social organisation of diasporic communities through social capital, social networks, and the relationships they build within host societies that allow them to maintain an ethnic identity and create links with countries of origin and paving the way for the need and/or desire to connect with one's heritage through travel, be it actual or imaginary. The example of the $1^{\text {st }}$ São Jorge Scouts Group provides and instructive case study into how Portuguese immigrants in Johannesburg, South Africa were able to create and maintain an identifiably Portuguese social group in the context of the international Scouting movement.

The paper begins by looking at the literature surrounding the links between diaspora and tourism, as well as the social organisation of diaspora, then outlines the historical background of Portuguese immigrants to South Africa as well as the historical context of the global and South African Scouting movement. Key findings from in-depth interviews with 10 members (both former and current) of the group reveal four areas of evidence akin to the characteristics of diasporic experiences elsewhere in the world.

\section{STUDY CONTEXT}

\section{Diasporas and Tourism}

Brubaker (2005: 1) argues that the term 'diaspora' has evolved over time and been stretched in many ways whilst expanding in interest beyond academia, particularly since the late 1980s. According to Alexander (2017: 1545) the term has increased alongside the study of migration and mobility, given the pace of transformation in the global north. Over time, the term has moved away from its original reference to Jewish diaspora and the notion of forced exile and into the idea of any migrant community that shares connections, be it sentimental or material to a common 'homeland' (King, 2012: 145).

Alongside diaspora, 'transnationalism' has also proliferated. Transnationalism refers to the "processes through which immigrants maintain social relations that connect their home country and host society" (Huang et al., 2013: 286). As such, advancements in technology and transportation allow for immigrants to effectively live in two worlds. A key element of transnantionalism is the array of transnational practices that immigrants engage themselves in to maintain the ties between home and their host country, which can include individual and collective activities, such as the ownership of or investment in real estate, attendance of home events, remittances to the home country, and the participation in associations and/or organisations, sports clubs, social groups (such as a Scouts group) and so on (Portes et al., 2002; Haller \& Landolt, 2005). Such activities have surfaced in the literature creating links between diaspora and tourism, particularly diaspora heritage tourism (Huang et al., 2013). In addition, several examples exist of studies on the travels of diasporic communities in search of their roots and heritage (see for example, Stephenson, 2002; Sim \& Leith, 2009; Hughes \& Allen, 2010; Iorio \& Corsale, 2012; Pelliccia, 2016; Io, 2017). Notwithstanding this body of research surrounding the travels of diasporic communities in search of their heritage, a knowledge gap exists about the social capital that such transnational practices bring to these communities. 


\section{The Social Organisation of Diaspora}

The integration of immigrant communities into host societies has been widely debated in the literature (see e.g., Phinney et al., 2002; Reitz, 2002; Van Oudenhoven et al., 2006). One aspect related to both the process of migration itself as well as the processes surrounding integration and adaption into host societies is that of the role and significance played by networks of kinship and friendship (Brettel, 2014). In this sense, networks and social organisations provide social capital and enable communities to maintain their identities and social ties both within their host community and the country of origin. In the same vein, immigrant organisations form important links to the country of origin and help to "create, express and maintain a collective identity" (Schrover \& Vermeulen, 2005: 823). The notion of social capital is an important feature of diaspora and immigrant literature and has roots in sociological discourse. Its definition, much like that of diaspora, has evolved over time to suit different contexts and levels of application (Sampson \& Graif, 2009; Portes, 1998). One of the earliest definitions of the term was by Bourdieu (1985: 248) that social capital is "the aggregate of the actual or potential resources which are linked to possession of a durable network of more or less institutionalized relationships of mutual acquaintance and recognition”. Other key early definitions have been provided by Loury (1977), Coleman (1988), Schiff (1992) and Burt (1992). Portes (1998) provides a more recent detailed discussion on the origins of social capital. Nevertheless, despite an array of definitions, in a more general sense social capital refers to the features of social groups in contemporary societies that includes a shared sense of identity, interpersonal relationships, mutual norms and values, trust, cooperation and importantly, reciprocity (Putnam, 1993; Coleman, 1998; Portes, 1998).

The idea of social capital being influenced by the role of migrant networks has also featured in academic inquiry (Anthias, 2007; Garip, 2008; Ryan et al., 2008; Morales \& Giugni, 2016) and filtered into tourism studies. Social capital is no stranger to tourism scholarship and mostly focused on communities at destinations and their reactions to tourism development, and entrepreneurship (Macbeth et al., 2008; McGehee et al., 2010; Zhao et al., 2011; Park et al., 2012; Park et al., 2014; Moscardo et al., 2017). One notable study on the links between tourism and social capital looks at the transnational social capital maintained by British retirees in Spain and the resultant VFR tourism flows (Casado-Díaz et al., 2014). However, despite the existence of this literature, there is limited attention on the social capital generated by specific social groups that spill into the discourse on the power of social capital and its links to identity and the desire to connect to one's heritage through travel.

\section{THE PORTUGUESE DIASPORA IN SOUTH AFRICA}

The Portuguese diaspora in South Africa have a long-standing history, dating back to the late $15^{\text {th }}$ century as a result of the early Portuguese explorers (Boxer, 1969; Axelson, 1990; Newitt, 2015). Bartholomeus Dias was the first of the Portuguese explorers to land in the Cape in 1486, later followed by Vasco da Gama in 1497. Although the connection between the two countries is ancient, it is the more contemporary groups of immigrants spanning between the 1800 s to the mid to late 1970 s that have resulted in the complex and varied diasporic settlement of the Portuguese in the country.

In his historical studies on Portuguese migration to South Africa, Glaser (2010, 2012, 2013) outlines three distinct groups of immigrants that can be identified. The first group refers to the Madeirans from the early 1800s to the 1970s (Glaser, 2010). This group consisted of mostly men that had been facing economic despair in their home country and were in search of a better life in South Africa, often entering the country 
illegally. They were typically later followed by their wives and children or on some occasions women would be sent over to become their wives and settle with them in their new home. The Madeirans were for the most part illiterate and lacked in skill but tended to stick together, offering employment to fellow Madeirans on and in their farms, shops, coffee houses and fishing endeavours. The second group of Portuguese immigrants saw a more literate and skilled populace from mainland Portugal between 1940 and 1980, with the most substantial concentration being between 1963 and 1971 (Glaser, 2012, 2013).

Despite experiencing similar economic challenges as the Madeirans, the mainlanders tended to be skilled in specific fields such as building, engineering and steel production and manufacturing, thus giving them a distinct advantage and appeal to the South African government who at the time was experiencing a severe skills shortage and preferred to support (white) immigrant skilled labour rather than relaxing policies on the employment of black South Africans (see Perbedy, 2009).

It is the third, and possibly most significant group of Portuguese immigrants to South Africa that saw a more visible and socially organized Portuguese identity in the country. This group included the Angolan and Mozambican Portuguese diaspora that had to flee their respective countries in the wake of civil war and decolonisation between 1974 and 1976 (Glaser, 2012, 2013). They made up the largest single event of Portuguese settlement in the country and differed greatly from the first two groups in that they were a privileged elite, highly educated and skilled professionals, many of whom had suffered great loss in both status and material possessions. With a pride for having a separate 'African identity', this last group of Portuguese-speaking immigrants introduced a variety of social and economic footprints in the form of societies, sports clubs, food, charity and media. One such example is that of the 1st São Jorge Scouts Group. Although all three groups feature in the literature it is the last two groups that managed to make the most visible social and economic impact especially in relation to residential enclaves particularly in the southern suburbs of Johannesburg (Cohen \& Hart, 1972; Harrison \& Zack, 2014; Moyo \& Cossa, 2015).

\section{THE GLOBAL AND SOUTH AFRICAN SCOUTING MOVEMENT}

The Scouting movement has been around since 1907, originally started by Lord Robert Baden-Powell with the intention of tapping into the unrealised potential of the British youth stemming from his experience as a soldier. The movement has since spread globally and currently has over 50 million members worldwide (WOSM, 2016, no date). According to their mission and vision statements, the Scouting movement is socially significant in that it aims at contributing to the education of young people with a focus on active citizenship (WOSM, 2014). The organisation can be considered a noteworthy example of the establishment of a group identity in itself as those who have been or are currently members can identify themselves as Scouts and part of a much larger collective social identity (Ashforth \& Mael, 1989; Jenkins, 2008). Literature surrounding the global Boy Scouts and Girl Guides movement largely has been linked to topics such as imperialism and war (Proctor, 2000, 2002; Warren, 2017), as well as active 'global' citizenship and its role in informal education (Vallory, 2012; Mills, 2013), and the gendered perspectives of girl guides and gay boy scouts (Proctor, 2009; Arneil, 2010; Mills, 2011; Martin, 2016; Halls et al., 2018). South Africa assumes an important role in the early history of the international Scouting movement. Its founder, Lord Baden-Powell, was stationed at Mafikeng during the Boer War as a Lieutenant-General.

During his duty in South Africa, he wrote a handbook titled "Aids to Scouting," which garnered him fame on his return home to Britain in 1903 as a national hero (Scouts 
South Africa, no date). Scouting was officially introduced in South Africa in 1908 (Scouts South Africa, no date), shortly after its launch in the UK in 1907. Some of the original groups of the Cape and the Transvaal are still in existence including $1^{\text {st }}$ Claremont in the Western Cape, and $1^{\text {st }}$ Kengray BK in Gauteng with roots to the $1^{\text {st }}$ Belgravia group, founded in 1908 (Scouts South Africa, no date). Currently, it is estimated that Scouts South Africa has over 308 ooo members across the country (Scouts South Africa, no date). In South Africa Scouts groups have formed for a variety of reasons; it is those that hold a specific ethnic identity that are of particular interest to this reserach.

In the Gauteng province, with Johannesburg as the major city, three groups stand out; these are the $1^{\text {st }}$ German, $1^{\text {st }}$ Hellenic, and $1^{\text {st }}$ São Jorge, respectively having distinct German, Greek and Portuguese identities. It is the $1^{\text {st }}$ São Jorge group which is the focus of this study as it relates to the significant history of Portuguese settlement in South Africa.

\section{CASE STUDY: THE $1^{\text {ST }}$ SÃO JORGE SCOUTS GROUP}

The $1^{\text {st }}$ São Jorge Scouts Group came into being when two families introduced the idea of Portuguese scouting in Johannesburg in July 1976. The group was originally named

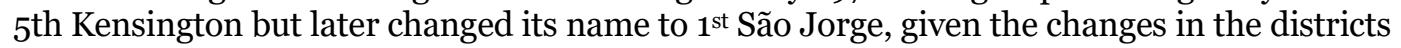
within the province. The new name was reflective of both their Portuguese heritage and the Catholic faith placed on the importance of saints. The group officially began on the $30^{\text {th }}$ of January 1977 and grew steadily in numbers, drawing many of its members from the Holy Angels Catholic Church's Portuguese parish base. The church is located in Bezuidenhout Valley, which was home to a predominantly Portuguese community (see Cohen \& Hart, 1972; Harrison \& Zack, 2014; Moyo \& Cossa, 2015) as well as also servicing a large English speaking community. The church and its hall (Marywill Hall, a separate property belonging to the church) became the group's home base with the full support of the then priest. Over the years the group's membership has fluctuated but throughout its existence has maintained a distinct Portuguese identity within the South African Scouting community as well as its surrounding Portuguese- and English-speaking communities.

\section{METHODOLOGY}

A qualitative research approach was used to examine the experiences of current and former members of the $1^{\text {st }}$ São Jorge Scouts Group. Such an approach allows for "understanding the world from the perspective of its participants" (Phillimore \& Goodson, 2004: 4). The research aimed to explore the scouts group as an example of the social organisation of the Portuguese community in South Africa. Since the group is based in Johannesburg, its network was geographically limited to its surroundings, and therefore influenced by activities related to the Portuguese community mostly around Johannesburg, the province of Gauteng and in some cases in other provinces of South Africa when participating in Scouting activities and trips. The study was conducted over January to March 2019, using in-depth semi-structured interviews as well as a range of documentary sources. A total of 10 detailed interviews were conducted, including 1 original founding member, 1 district commissioner, 1 group scouter, 1 former scout leader, 1 former parent and parents' association secretary, and 5 former Scouts.

In addition, a variety of materials such as minutes of meetings from the parents' association, group photo albums, and their collection of newspaper and magazine clippings were also analysed for content where evidence of their activities and social identity was documented. It is important to note that the group is still in existence today, albeit on a different property. However, the findings are written in past tense as the experiences of the interviewees range from the group's beginnings to around the early 
2000s, with the exception of the Group Scouter and the District Commissioner, both of whom are still active. Table 1 below depicts information regarding the interviewees and the relevant codes to identify each interviewee in the discussions that follow:

Table 1. Profile of Interviewees

\begin{tabular}{|c|c|c|c|}
\hline Interviewee Number & Role & Gender & Age Group \\
\hline F1 & One of the original founders & Male & $60-70$ \\
\hline GS & Group Scouter & Male & $70-80$ \\
\hline DC & Disctrict Commissioner & Female & $70-80$ \\
\hline SL & Former Scout Leader (cubs) & Female & $30-40$ \\
\hline P1 & Former Parent andParents Association Secretary & Female & $60-70$ \\
\hline S1 & Former Scout & Male & $30-40$ \\
\hline S2 & Former Scout & Male & $30-40$ \\
\hline S3 & Former Scout & Male & $30-40$ \\
\hline S4 & Former Scout & Male & $20-30$ \\
\hline S5 & Former Scout & Female & $20-30$ \\
\hline
\end{tabular}

\section{FINDINGS}

Four key themes were identified from the responses of the interviewees. These include: aspects of identity, the group's frequent representation in the media, the role of the Holy Angels Catholic Church, and an ongoing sense of community with support particularly from the Portuguese community at large, both locally and internationally, as well as the social capital gained from participating in the group.

\section{Identity}

Identity plays a significant role in the study of migration and diaspora and has featured substantially in academic literature (Boyarin \& Boyarin, 1993; Gilroy, 1997; Georgiou, 2006; Ben-Moshe \& Segev, 2007; Hall, 2014). The 1st São Jorge Scouts Group seems to hold two definitive identities: the first being a respected representative of the Portuguese community in Johannesburg and South Africa, and the second being a beloved South African Scouts group while being a part of the bigger global Scouting movement.



Figure 1. Example of the uniform

(Source: Group Scouter's personal archive - left, and Author's personal archive - right) 
The group successfully built and maintained an identity within the South African Portuguese community in a variety of ways. The uniform (Figure 1), for instance, indicated elements of Portuguese identity. The traditional Scout uniform in South Africa includes khaki pants but the group requested to be able to wear navy pants to match those of Scouts in Portugal. The scarf also distinguished them as Portuguese, being red with a white trim, representing both the prominent red colour of the Portuguese flag and the red and white colours associated with São Jorge. The emblem included at the point of the scarf is green with an embroided golden cross similar to that of the Portuguese order of Christ and the crosses of Portuguese explorers. The parents would wear an inverted scarf (no uniform) at events and fundraisers that was white with a red trim and had the same green badge.

Despite, according to one of the original founders, the group's intention not initially being to become a specifically Portuguese group, the general composition of the group was, for the most part, of Portuguese descent given its geographical location:

„...we registered as an ordinary Scouts group, an open Scouts group so it was not a Scouts group that was only for Portuguese people, it was not a Scouts group that was only for Roman Catholic people. So it was an open group, Roman Catholic base, Portuguese base but open to any kids of any religion, and of any race, and of any background whatsoever... but when we started, $100 \%$ of the kids were of Portuguese origin" (F1).

The parents were mainly first generation immigrants and the children which they enrolled in the group were likely to be second or third generation and holders of both South African and Portuguese passports. Although the group was mostly made up of Portuguese members, the group was open to anyone who wanted to join and several members had no relation to Portuguese culture or identity:

„It [the group] actually pulled all the Portuguese community together, not just Portuguese, I mean there were other kids that were not Portuguese speaking... We never turned anyone down... [but] to me I see it as a Portuguese group" (SL).

This being said, for those who did hold a Portuguese passport, its value was undeniably held in high esteem:

"It's gold [the Portuguese passport], it gives travel opportunities, it gives immigration opportunities, it basically is just like and Ace in the pocket, like if anything happens I've got that to fall back on" (S1).

When asked about whether being part of the 1st São Jorge Scouts Group added to their Portuguese identity, most interviewees agreed that it played a moderate to significant role in their Portuguese identity:

"It [being part of the group] gives you major Portuguese points... it is the Portuguese thing to do because then you start mingling with all the Portuguese people" (S1).

Language is linked to the experiences of immigrant and diasporic communities in terms of the preservation of their culture and identity. The mother tongue of immigrants is often lost through subsequent generations (Alba et al., 2002; Rumbaut, 2002). Although the scouts themselves largely spoke English amongst themselves, Portuguese was widely spoken by the parents and their children who had heard it regularly at home, church, and at Scouts, with some attending Portuguese classes after school. In addition, the group was frequently represented as an important part of the Portuguese community often appearing alongside the Portuguese Consulate as part of the annual 10th of June 
Social Capital and the Making of Diaspora:

Evidence from the Portuguese Community in Johannesburg, South Africa

Portugal Day celebrations. The decisions made by the interviewees and their parents to join the group evidenced the desire to fit into a similar culture and to be amongst people who spoke the same language:

"It's just easier... if you're coming from overseas and you speak Portuguese...

if it's like-minded people and people from a similar culture you should fit right in, even though its not family it will feel like family pretty quickly" (S1).

"My parents would not have let me join [just] any group, they were very protective so because it was Portuguese, they would trust them more" (SL).

Being part of the local and global Scouting movement, interviewees indicated significant pride in being identified as a Scout or a member of a Scout group, with the Scouts, in particular, indicating that they had included being a Scout as part of their early Curriculum Vitae in search of work:

"It's always a good thing to say that you were part of Scouts...it's one of those things, you're always a Scout" (S1).

The group was also fondly recalled by the District Commissioner as being special and a welcoming group that felt like home. Indeed, it is clear that the group was well-liked and easily identifiable among the rest of the Scout groups in the district:

"...if you're asking on a personality thing [the group], it has enormous warmth, it really does... and they are very, very inclusive of one, which is also a little bit unusual, you know you don't feel I'm the odd one out when you go there" (DC).

\section{Representation in the media}

Media - local, regional or international - plays an important role in the lives of diasporic communities. In academic literature, the role of the media has featured in terms of maintaining links to the homeland by keeping up to date with news and events as well as of the media's representation of diaspora (Georigiou, 2006; Bailey et al., 2007).

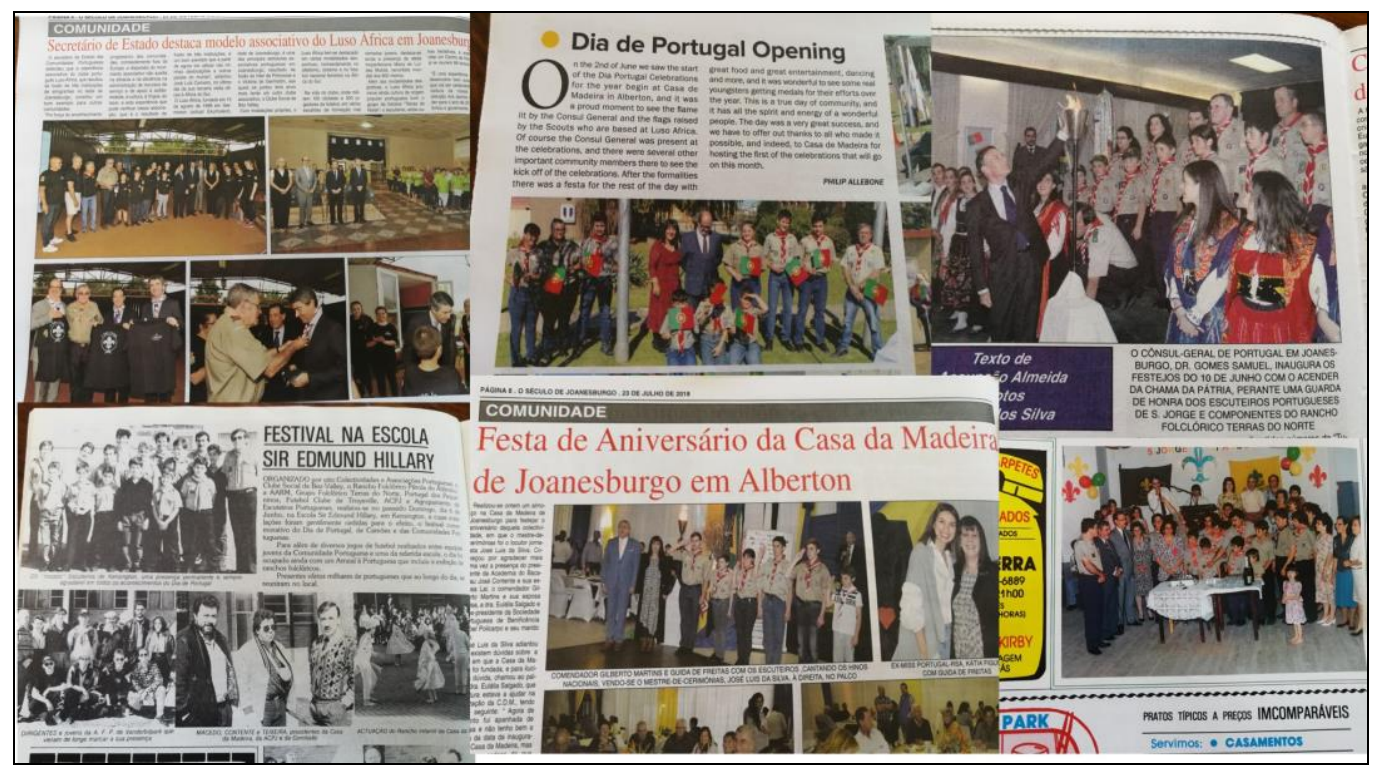

Figure 2. Examples of publications that the group featured in (Source: Group Scouter's personal archive) 
More recently, besides its obvious use as a means for communictaion between transnational connections and the creation and maintanence of identities, social media has also widely been used in the representation of diasporic communities (Mainsah, 2011; Komito, 2011; Bacigalupe \& Camara, 2012). For the 1st São Jorge Scouts Group, the print media was a significant roleplayer in both the creation of its identity as well as cementing the group's visual presence within the South African Portuguese community.

The Scout group was frequently featured in an array of ethnic media including newspapers and magazines (Figure 2 above). These included Jornal Popular during the 1970 s and 1980s (no longer in circulation) and $O$ Século, a Portuguese language newspaper (started in 1963) based in Johannesburg, claiming to have a circulation of 40000 and readership of over 200000 (Glaser, 2012). The latter featured local news stories of people from the Portuguese community as well as an obituary section. Other important media were Vóz Portuguesa, a more modern newspaper by the Portuguese Forum, including articles in Portuguese and English; Notícia, a Portuguese magazine no longer in circulation, often sold alongside $O$ Século featuring stories of local people and organisations within the Portuguese community and also served for the advertisement of Portuguese-owned businesses and services. The group also featured in interviews and snippets of Portuguese day celebrations on television shows (both locally and internationally) dedicated to Portuguese diasporic communities available on local service provider, M-Net and DSTV, which made $M$-Net Portuguesa available to the Portuguese community through subscriptions to their digital satellite television service, and also offers Brazilian channels and a dedicated local sports channel in Portuguese:

„RTP International [a Portuguese television network] would say we are going to cover such and such a topic on whatever day, we need the consulate to give us a list of the communities [and groups] that exist in South Africa and so the Scouts were invited for those specific events because we are part of the [Portuguese] community, they [the consulate] know that we exist so we would get a written invite" (GS).

This kind of exposure through media meant that the group was constantly visible in the eyes of the Portuguese community that engaged with the content provided through this media available in their own language. The media stories portrayed the group as proud of and participating in Portuguese celebrations and, on occasion, its visits to old people and pursuit of charity work.

\section{The role of the church}

Churches have been a common feature in the literature surrounding diasporic communities. Several studies investigate the role that churches and other faith-based organizations have as key points of transition and integration into the host society (Appleby, 2011; Mensah et al., 2013; Tsang, 2015), most especially amongst refugees and internally displaced people (Parsitau, 2011; Snyder, 2011). The Holy Angels Catholic Church is based in Bezuidenhout Valley, a suburb just outside of the Johannesburg CBD. The suburb was once home to a prominent Portuguese and Italian community. The church largely served the surrounding Portuguese and English speaking community with separate masses held in Portuguese and English. During the late 1970 s when the 1st São Jorge Scouts Group first came into being the (then) priest was interested in the group's aims to service the local youth and extended his support by offering them a space to operate from. The church property, Marywill Hall, on the adjacent block, was home to the group's meetings, activities and fundraising initiatives. Throughout the duration of the group's stay on the church property, the scout group was highly visible in church activities. The Portuguese speaking parish base of the church was a significant source of 
the group's membership. Once a month the group would be present at Sunday mass in full uniform at the front of the church, and would participate regularly in church fundraising events as well as charitable initiatives:

,... [the] majority of the people that went to the group attended the church so they'd be at mass on a Sunday... so with the church functions like with their annual party [to raise funds for the church], we used to go as a Scout group and they had a Portuguese stall [where] the parents did the farturas and maybe pregos... but we were involved in that way" $\left(\mathrm{S}_{3}\right)$.

„,...once a month, we used to stand in front of the church for the whole mass... they [the church] included us as part of their parish... if we as the Scouts had functions we would advertise it at the church as well and we would have the support from them and vice versa" ( 44 ).

\section{Sense of community, support and social capital}

A key element of the settlement and integration of diasporic communities is that a sense of community and belonging. When the culture and language of the host society is different from the diasporic community often they can find solace in sticking together. All interviewees indicated that the Scout group brought a sense of family and built a tight network of people that worked hard to maintain it:

"I thought it was awesome, it was like family... it was quite a closely-knit community..." (S1).

,... [it's] almost an alumni that exists between everybody that has gone through it and I think it played a very important role, a different role in everyone's life... you almost have a [sense of] pride when you have to give back or are asked to give back" (S2).

One of the parents and former Parents Association secretary, recalls how the group provided herself, like many others, the opportunity to provide hers and other children with important opportunities through the dedication and work of the parents whilst also giving back to the larger Portuguese community:

„....when you work for a group like this one, you're not only working for one person, you're working for many people inside the group and outside the group because the parents association doesn't raise funds just for the group, the group has also assisted other people in the community" ( $\mathrm{P} 1)$.

The value of the social connections and networks established between the members of the group was also emphasised by interviewees:

"You make social connections, it's a social place to be, its a fun place to be, you have something to do every week, every Friday. It probably kept me out [of trouble] because it was a Friday night and we wouldn't go drinking, we'd actually sit there and make some use of our life and now it's just the connections, people that you know that you can pull on in your network, friends that you can call up every once in a while" $(\mathrm{S} 1)$.

The role of the parents association was significant and most influential and compared differently to parents in local non-Portuguese Scouts groups. In its activities elements of Portuguese culture and traditions came through strongly through the use of food, both at gatherings at Scouting events as well as in their own fundraising events and those of the church:

"There was this thing called Kontiki that we used to do, it was a boat race thing. With the Portuguese scouts group, all of the families kind of knew each 
other and when it came to food and setting up the tent and having the whole base camp set up, everybody would be there, family and friends so we would have one of the most rocking base camps around and that I think came from the Portuguese aspect that other camps wouldn't have. They'd have to work a lot harder to get people to come and volunteer like that..." (S1).

Indeed, the on-going recognition and respect by the larger Portuguese community recorded in the presence of the group in Portuguese media further entrenched the group's social capital value within the community. The presence of and recognition by the Portuguese consulate of Johannesburg further highlighted the support from the local Portuguese community from the highest level and resulted in the group being invited to represent both the Scouting movement in general and the South African Portuguese community at locally hosted Portuguese events such as the 10th of June Portuguese Day celebrations, monthly representation during masses at the Holy Angels Catholic church, and calls for assistance by the group at local Portuguese cultural events such as the Lusito Land festival and at various children and old age homes around Johannesburg.

An interesting feature of the interviewee experience, specifically among the Scouts and which stems from the fundraising support provided by the parents association, was the opportunity for domestic travel due to camping, hiking and competitions with other Scout groups. Some of these experiences were described as lifechanging experiences to a degree, putting them to the test and in turn learning essential life skills:

"Cederberg [a mountain range in the Western Cape]... it was just like, throw you in the deep end, 10 days in the middle of nowhere, 40 degree [celsius] heat, good fun, like-minded people... like sometimes I wish I could just go back and do a Cederberg hike if I was busy with the group again.” (S1).

„...it's awesome to socialise with different people... also teaching you to survive, it teaches a lot of life skills, and learning to work with people, surviving out there in different conditions... and also teamwork within the group" ( 55 ).

The interviewees also indicated that despite some of the parents perhaps having had the means to provide travel and other opportunities for their children, many of the scouts particularly towards the end of the 1990s did not have parents who had the means to do so:

„I think the the Scout [group] also started changing and I think that was also based on our location where if your'e looking at a bigger, maybe $10 \mathrm{~km}$ radius, there was a lot more poverty in the area than when it was initially established... where we started seeing people started joining the Scout [group] coming from almost a bit of a more lower class... not as priviledged backgrounds. And I think the Scouting movement did give these individuals a slightly different aspect and look at life... and it did expose them to things that they possibly would not have been exposed to" (S2).

Thus, the opportunities provided by the group for these chidren echo the similar efforts of other organisations in South Africa with the aim of exposing children to travel and other parts of the country which they would not have otherwise had the opportunity to do so (Adinolfi \& Ivanovic, 2015).

\section{CONCLUSION}

Research and scholarship on diaspora and tourism is of expanding interest. Currently, however, there are only limited investigations concerning the lived experiences of diasporic communities. This paper addresses the manner in which diasporic 
communities organise themselves socially, economically and politically whilst integrating into the host community. In particular, a specific focus was upon the role of social capital and networks. The 1st São Jorge Scouts Group provides a useful lens into the efforts of the Portuguese diaspora in Johannesburg attempting to preserve its homeland culture whilst at the same time meeting the goals and vision of the global Scouting movement. The group, established in 1977, facilitated a platform for Portuguese immigrants to socialize and provide educational experiences for their children. With a catholic church that had a significantly Portuguese parish base, being the group's home base for the majority of its existence and recognition by the Portuguese consulate, the group encompassed several aspects of Portuguese identity. Overall, the research discloses the vital role of social capital and networks in the construction of Portuguese identity and contributes to a larger discourse on immigrant integration, sense of belonging and links to tourism.

\section{Acknowledgements}

An earlier version of this paper was presented at the Annual Meeting of the Association of American Geographers (AAG) held in Washington DC, USA, on 3-7 April 2019.

\section{REFERENCES}

Adinolfi, M.C. \& Ivanovic, M. (2015). Recounting Social Tourism Development in South Africa. African Journal for Physical Health Education, Recreation and Dance, 21 (Supplement 2), 1-12.

Appleby, J.K. (2011). The Role of the Catholic Church in Immigrant Integration. The Review of Faith \& International Affairs, 9 (1), 67-70.

Alba, R., Logan, J., Lutz, A. \& Stults, B. (2002). Only English by the Third Generation? Loss and Preservation of the Mother Tongue among the Grandchildren of Contemporary Immigrants. Demography, 39 (3), 467-484.

Alexander, C. (2017). Beyond „The ,diaspora' diaspora”: A response to Rogers Brubaker. Ethnic and Racial Studies, 40 (9), 1544-1555.

Anthias, F. (2007). Ethnic Ties: Social Capital and the Question of Mobilisability. The Sociological Review, 55 (4), $788-805$.

Arneil, B. (2010). Gender, Diversity, and Organisational Change: The Boy Scouts vs Girl Scouts of America. Perspectives on Politics, 8 (1), 53-68.

Ashforth, B.E. \& Mael, F. (1989). Social Identity Theory and Organisation. Academy of Management Review, 14 (1), $20-39$.

Axelson, E. (1900). Portuguese Pioneers in South Africa. South African Broadcasting Corporation (SABC), Johannesburg: The Swan Press Limited.

Bacigalupe, G. \& Camara, M. (2012). Transnational Families and Social Technologies: Reassessing Immigration Psychology. Journal of Ethnic and Migration Studies, 38 (9), 1425-1438.

Bailey, O.G., Georgiou, M. \& Harindranath, R. (2007). Transnational Lives and the Media. Hampshire, UK: Palgrave Macmillan.

Ben-Moshe, D. \& Segev, Z. (2007). Israel, the Diaspora and Jewish Identity. England: Sussex Academic Press.

Bourdieu, P. (1985). The Forms of Capital. In Richardson, J.G. Handbook of Theory and Research for the Sociology of Education. New York: Greenwod.

Boxer, C. R. (1969). The Portuguese Seaborne Empire, 1415-1825. London: Hutchinson.

Boyarin, D. \& Boyarin, J. (1993). Diaspora: Generation and the Ground of Jewish Identity. Critical Inquiry, 19 (4), $693-725$.

Brettell, C.B. (2014). Theorizing Migration in Anthropology: The Cultural, Social and Phenomenological Dimensions of Movement. In Brettel, C.B \& Hollifield, J.F. (Eds.). Migration: Talking Across Disciplines (3rd Ed.). New York: Routledge.

Brubaker, R. (2005). The 'Diaspora' Diaspora. Ethnic and Racial Studies, 28 (1), 1-19.

Burt, R.S. (1992). Structural Holes, The Social Structure of Competition. Cambridge, MA: Harvard University Press.

Casado-Díaz, M.A., Casado-Díaz, A.B. \& Casado-Díaz, J.M. (2014). Linking Tourism, Retirement Migration and Social Capital. Tourism Geographies, 16 (1), 124-140.

Cohen, S. \& Hart, G.H.T. (1972). Clustering Characteristics of a Migrant Community in the Core of the Primate Centre. South African Geographical Journal, 54 (1), 84-94.

Cohen, R. (1997). Global Diasporas. London: Routledge.

Coleman, J.S. (1988). Social Capital in the Creation of Human Capital. American Journal of Sociology, 94, S95-121.

Garip, F. (2008). Social Capital and Migration: How do Similar Resources Lead to Divergent Outcomes? Demography, 45 (3), 591-617.

Georgiou, M. (2006). Diaspora, Identity and the Media: Diasporic Transnationalism and Mediated Spatialities. USA: Hampton Press. 
Gilroy, P. (1997). Diaspora and the Detours of Identity. In Woodward, K. (Ed.). Culture, Media and Identities. Identity and Difference. UK: Sage Publications, 299-346.

Glaser, C. (2010). Portuguese Immigrant History in Twentieth Century South Africa: A Preliminary Review. African Historical Review, 42 (2), 61-83.

Glaser, C. (2012). Home, Farm and Shop: The Migration of Madeiran Women to South Africa, 1900-1980. Journal of Southern African Studies, 38 (4), 885-897.

Glaser, C. (2013). White but Illegal: Undocumented Madeiran Immigration to South Africa, 1920s-1970s. Immigrants \& Minorities, 31 (1), 74-98.

Greenman, E. \& Xie, Y. (2008). Is Assimilation Theory Dead? The Effect of Assimilation on Adolescent WellBeing. Social Science Research, 37 (1), 109-137.

Hall, S. (2014). Cultural Identity and Diaspora. In Mirzoeff, N. (Ed.) (2014). Diaspora and Visual Culture: Representing Africans and Jews. New York: Routledge, 21-33.

Haller, W. \& Landolt, P. (2005). The Transnational Identities Dimensions of Identity Formation: Adult Children of Immigrants in Miami. Ethnic and Racial Studies, 28 (6), 1182-1214.

Halls, A., Uprichard, E. \& Jackson, C. (2018). Changing Girlhoods - Changing Girl Guiding, The Sociological Review, 66 (1), 257-272.

Harrison, P. \& Zack, T. (2014). Between the Ordinary and the Extraordinary: Socio-spatial Transformations in the 'Old South' of Johannesburg. South African Geographical Journal, 96 (2), 180-197.

Huang, W., Haller, W.J. \& Ramshaw, G.P. (2013). Diaspora Tourism and Homeland Attachment: An Exploratory Analysis. Tourism Analysis, 18, 285-296.

Hughes, H. \& Allen, D. (2010). Holidays of the Irish Diaspora: The Pull of the 'Homeland'? Current Issues in Tourism, 13 (1), 1-19.

Io, M. (2017). Exploring the motivation of Chinese Immigrants for Homeland Tourism. Current Issues in Tourism, 20 (5), 521-535.

Iorio, M. \& Corsale, A. (2012). Diaspora and Tourism: Transylvanian Saxons Visiting the Homeland. Tourism Geographies, 15 (2), 198-232.

Jenkins, R. (2008). Social Identity, 3rd Edition. UK: Routledge.

King, R. (2012). Geography and Migration Studies: Retrospect and Prospect. Population, Space and Place, 18, $134-153$.

Komito, L. (2011). Social Media and Migration: Virtual Community 2.o. Journal of the American Society for Information Science and Technology, 62 (6), 1075-1086.

Loury, G.C. (1977). A Dynamic Theory of Racial Income Differences. In Wallace, P.A. \& La Mond, A.M. (Eds.). Women, Minorities, and Emploment Discrimination. Lexington, MA: Heath.

Macbeth, J., Carson, D. \& Northcote, J. (2008). Social Capital, Tourism and Regional Development: SPCC as a Basis for Innovation and Sustainability. Current Issues in Tourism, 7 (6), 502-522.

Mainsah, H. (2011). ,I could well have said I was Norwegian but nobody would believe me': Ethnic Minority Youths' self-representation on social network sites. European Journal of Cultural Studies, 14 (2), 179-193.

Martin, M.C. (2016). Race, Indigeneity and the Baden-Powell Girl Guides: Age, Gender, and the British World, 1908-1920. In Robinson, S. \& Sleight, S. (Eds.). Children, Childhood and Youth in the British World. London: Palgrave Macmillan, 161-179.

McGehee, N.G., Lee, S. O’Bannon, T.L. \& Perdue, R.R. (2010). Tourism-related Social Capital and it's Relationship with Other Forms of Capital: An Exploratory Study. Journal of Travel Research, 49 (4), 486-500.

Mensah, J., Williams, C.J., Aryee, E. (2013). Gender, power, and religious transnationalism among the African diaspora in Canada. African Geographical Review, 32 (2), 157-171.

Mills, S. (2011). Scouting for Girls? Gender and the Scout Movement in Britain. Gender, Place \& Culture, A Journal of Feminist Geography, 18 (4), 537-556.

Mills, S. (2013). "An Instruction in Good Citizenship": Scouting and the Historical Geographies of Citizenship Education. Transactions of the Institute of British Geographers, 38 (1), 120-134.

Morales, L. \& Giugni, M. (Eds.) (2016). Social Capital, Political Participation and Migration in Europe. UK: Palgrave Macmillan.

Moscardo, G., Konovalov, E., Murphy, L., McGehee, N.G. \& Schurmann, A. (2017). Linking Tourism to Social Capital in Destination Communities. Journal of Destination Marketing \& Management, 6 (4), $286-295$.

Moyo, K. \& Cossa, E. (2015). 'Ethnic Enclave of a Special Sort?' Mozambicans in La Rochelle, Johannesburg. Journal of Southern African Studies, 41 (1), 141-158.

Newitt, M.D.D. (2015). Emigration and the Sea, an Alternative History of Portugal and the Portuguese. London: Hurst \& Company.

Park, D., Lee, K., Choi, H. \& Yoon, Y. (2012). Factors Influencing Social Capital in Rural Tourism Communities in South Korea. Tourism Management, 33 (6), 1511-1520.

Park, D. Nunkoo, R. \& Yoon, Y. (2014). Rural Residents' Attitudes to Tourism and the Moderating Effects of Social Capital. Tourism Geographies, 17 (1), 112-133.

Parsitau, D.S. (2011). The Role of Faith and Faith-based Organizations among Internally Displaced People in Kenya. Journal of Refugee Studies, 24 (3), 493-512. 
Social Capital and the Making of Diaspora:

Evidence from the Portuguese Community in Johannesburg, South Africa

Pelliccia, A. (2016). In the Family Home: Roots Tourism among Greek Second Generation in Italy. Current Issues in Tourism, 21 (18), 2108-2123.

Perbedy, S. (2009). Selecting Immigrants: National Identity and South Africa's Immigration Policies, 19102008. South Africa: Wits University Press.

Phillimore, J. \& Goodson, L. (Eds.) (2004). Qualitative Research in Tourism. Ontologies, Epistemologies, Methodologies. New York: Routledge.

Phinney, J.S., Horenczyk, G., Liebkind, K. \& Vedder, P. (2002). Ethnic Identity, Immigration, and Well-Being: An Interactional Perspective. Journal of Social Issues, 57 (3), 493-510.

Piedra, L.M. \& Engstrom, D.W. (2009). Segmented Assimilation Theory and the Life Model: An Integrated Approach to Understanding Immigrants and their Children. Social Work, 54 (3), 270-277.

Portes, A. (1998). Social Capital: Its Origins and Applications in Modern Sociology. Annual Review of Sociology, 24, 1-24.

Portes, A., Haller, W.J. \& Guarnizo, L.E. (2002). Transnational Entrepreneurs: An alternative form of Immigrant Economic Adaptation. American Sociological Review, 67 (2), 278-298.

Proctor, T.M. (2000). "A Separate Path": Scouting and Guiding in Interwar South Africa. Comparative Studies in Society and History, 42 (3), 605-631.

Proctor, T.M. (2002). On My Honour: Guides and Scouts in Interwar Britain. Transactions of the American Philosophical Society, 92 (2), i-180.

Proctor, T.M. (2009). Scouting for Girls: A Century of Girl Guides and Girls Scouts. USA: Praeger ABC-CLIO LLC.

Putnam, R.D. (1993). The Prosperous Community: Social Capital and Public Life. The American Prospect, 4 (13), 35-42

Quayson, A. \& Daswani, G. (Eds.) (2013). A Companion to Diaspora and Transnationalism. London: Wiley Blackwell.

Reitz, J.G. (2002). Host Societies and the Reception of Immigrants: Research Themes, Emerging Theories and Methodological Issues. International Migration Review, 36 (4), 1005-1019.

Rogerson, C.M. (2017). Visiting Friends and Relatives Travel Matters for Sub-Saharan Africa. African Journal for Hospitality, Tourism and Leisure, 6 (3), 1-10.

Rogerson, C.M. \& Hoogendoorn, G. (2014). VFR Travel and Second Home Tourism: The Missing Link? The Case of South Africa. Tourism Review International, 18 (3), 167-178.

Rumbaut, R.G. (2002). Severed or Sustained Attachments? Language, Identity and Imagined Communities in the Post-Immigration Generation. In Levitt, P. \& Waters, M.C. (Eds.). The Changing Face of Home: The Transnational Lives of the Second Generation. New York: Russel Sage Foundation.

Ryan, L., Sales, R., Tilki, M. \& Siara, B. (2008). Social Networks, Social Support and Social Capital: The Experiences of Recent Polish Migrants in London. Sociology, 42 (4), 672-69o.

Sampson, R.J. \& Graif, C. (2009). Neighbourhood Social Capital as Differential Social Organization: Resident and Leadership Dimensions. American Behavioral Scientist, 52 (11), 1579-1605.

Schiff, M. (1992). Social Capital, Labour Mobility and Welfare: The Impact of Uniting States. Rationality and Society, 4 (2), 157-175.

Schneider, J. \& Crul, M. (2010). New Insights into Assimilation and Integration Theory: Introduction to the Special Issue. Ethnic and Racial Studies, 33 (7), 1143-1148.

Schrover, M. \& Vermeulen, F. (2005). Immigrant Organisations. Journal of Ethnic and Migration Studies, 31 (5), 823-832.

Snyder, S. (2011). Un/setting Angels: Faith-Based Organizations and Asylum-Seeking in the UK. Journal of Refugee Studies, 24 (3), 565-585.

Sim, D. \& Leith, M. (2009). Diaspora Tourists and the Scottish Homecoming. Journal of Heritage Tourism, 8 (4), 259-274.

Stephenson, M.L. (2002). Travelling to the Ancestral Homelands: The Aspirations and Experiences of a UK Caribbean Community. Current Issues in Tourism, 5 (5), 378-425.

Tsang, W.Y. (2015). Integration of Immigrants: The Role of Ethnic Churches. International Migration \& Integration, 16 (4), 1177-1193.

Vallory, E. (2012). World Scouting: Educating for Global Citizenship. Palgrave Macmillan, USA.

Van Oudenhoven, J.P., Ward, C. \& Masgoret, A. (2006). Patterns of Relations between Immigrants and Host Societies. International Journal of Intercultural Relations, 30 (6), 637-651.

Warren, A. (2017). Citizens of the Empire: Baden-Powell, Scouts and Guides, and an Imperial Ideal. Imperialism and Culture. In MacKenzie, J.M. Imperialism and Popular Culture, Manchester University Press, UK,

Zhao, W., Ritchie, J.R.B. \& Echtner, C.M. (2011). Social Capital and Tourism Entrepreneurship. Annals of Tourism Research, 38 (4), 1570-1593.

*** Scouts South Africa. (no date). Our History. Available at: https://www.scouts.org.za/about-us/our-history/. Accessed: 28 February 2019.

*** WOSM. (2016). Grand Total Membership Census (WOSM \& non-WOSM) with Gender as at 31 December 2016. Available at: https://www.scout.org/sites/default/files/library_files/Grand\%20Total\%20 Membership\%20with\%20Genders\%20at\%2031\%20Dec\%202016_o.pdf. Accessed: 28 February 2019.

**** WOSM. (no date). The Story of Scouting. Available at: https://www.scout.org/scout-history. Accessed: 28.02.2019.

Submitted:

07.02.2019
Revised:

04.06.2019
Accepted and published online 27.06.2019 